\title{
Development of a Learning Module Of Writing Debate Text Based Problem Based Learning (PBL)
}

\author{
Aditya Agung Pradita, Syahrul R, Yasnur Asri \\ Masters Program in Language and Literature Education Indonesia \\ Universitas Negeri Padang \\ praditaadityaagung@gmail.com
}

\begin{abstract}
This study was conducted to address the limitations Indonesian teaching materials on learning to write text debate class $X$ SMA Padang. The purpose of this study were (1) to explain the process of developing learning modules write text-based discussion of problem based learning (PBL) are valid, practical, and effective; and (2) to produce learning modules write textbased discussion of problem based learning (PBL) are valid, practical, and effective, to improve student learning outcomes in class X SMA Padang. This type of research is the $R \& D$ (research \& development). Development model used is the 4-D (define, design, develop, and dessiminate). The research subjects were class $X$ students of SMA $N 7$ Padang whose students numbered 28 people.
\end{abstract}

Keywords-module; text debates; PBL

\section{INTRODUCTION}

Writing is one of the aspects of language skills that must be mastered by the student. By writing, students are able to play an active role in learning and being able to organize information. Melida, Sinaga, \& Feranie (2016) state that writing can be seen as a tool that can build a useful knowledge to help students in the meta-cognitive, play an active role in learning and connecting prior knowledge.

Curriculum learning Indonesian in 2013 is a text-based learning. Learning is implemented by applying the principle that the language should be viewed as text, not merely a collection of words or linguistic rules. The use of language is a process of election forms to express the meaning of language. Functional languages, namely the use of language can never be separated from the context. Language is a means of forming ability of human thinking (Mahsun, 2014). According to the text-based term Sufanti (2013) is learning to make the text as the basis, principle, base and pedestal. This is due to the text is a complete expression of the human mind which may have had situations and contexts. Every text has its own structure that is different from one another.

Debate is one type of genre text argument. In addition students may submit his arguments in accordance with the data that has been met, the text of this debate also aims to develop students' critical thinking. This is in line with the opinion of Darby (2007) which says that the debate is one kind of active learning tools that promote critical thinking such as analysis, synthesis, and evaluation (Park Kier, and Jugdev, 2011). Further, according to Huryn (1986), the debate provides students experience some perception of how the student's knowledge must be sought not only from empirical research but also collect and analyze the data (Park Kier, and Jugdev, 2011)

Based on these objectives, it is important for students to learn the text of the debate. This is supported by a statement Adnyana, Suarni, \& Koyan (2014), that this debate is to train students' critical thinking, communication skills of students, to solve the problem in question, and maintain and affect the thoughts and opinions of others. Additionally, Musirah (2016) said that the purpose of this debate is kosep solidify students' understanding of the issues debated, trains students to be critical, and train students to dare to express.

Facts on the field showed that there is still a problem in writing the text of the student debate. These problems are as follows. First, students learn less varied sources. Second, learning is still dominated by the teacher. Third, teachers do not make their own teaching materials, because the material to be taught already in textbooks. Fourth, the books available in the library has not been much debate as to the text. Fifth, the text of debate is text that is relatively new in the Indonesian subjects.

Based on these problems, the most fundamental thing is the lack of learning resources used by students. Student learning resources used in the teaching of writing texts debate only one. The book is a handbook entitled Indonesian students published by the Ministry of Education and Culture of the Republic of Indonesia revised edition in 2016 which is the main learning resources used in the teaching of writing texts debate. The book can be obtained through a lending library of teaching sekolah.Bahan used only limited students' books. The lack of use of learning resources proved not to develop students' writing ability. Festiana, I., Sarwanto, \& Sukarmin (2014) says that the source and medium of learning is something very important in the learning process because it can be one of the critical success factors of learning that helps students and teachers to enhance the creative abilities. 
Based on the problems that have been explained, the solution that can be done is to develop learning resources that can be used to support the use of the main book. One of the learning resources created by the teacher is the learning module. The learning module is one of the guidelines for teachers to facilitate the delivery of material. The learning module aims to enable students to learn independently without teacher guidance. This was supported by the opinion of Yulastri, et al. (2017) which says the benefits of the module are to support existing teaching materials, to provide opportunities for students to learn independently with the concepts described in the module, and to improve student competencies. The modules developed are not only in accordance with the curriculum, but must pay attention to interesting language and appearance. This is in accordance with the opinion of Angin T.B.B, \& Syahrul. R. (2015) who said that a good module is a module that pays attention to language and an attractive appearance, making it easier for students to understand the content of the material in the module. In accordance with this opinion, the learning module functions for students as a guide that directs all activities in the learning process. Therefore, with the use of developed modules, it is expected that student learning outcomes are better than before.

Learning modules can be developed to load a model, method, or an appropriate learning approach (Roselina, 2014; Saputro, 2017). Based on this, the learning module was developed using problem based learning (PBL). Selection of PBL as a base learning module was motivated by several previous studies that show that learning using learning modules have better learning outcomes than learning not to use the learning module (Husniati, A., Suciati, S., \& Maridi, M. 2016; Khayati, F., Sujadi, I., \& Saputro, D. R. S. 2016).

Problem-based learning (PBL) is a learning model in which departs from the problem. Therefore, the problems are the main basis is authentic problems. That is, the problem can be found in everyday life. In connection that, Tik (2014) says that the design of PBL problems is a critical step because of the PBL is built around the problem. Not only that, Hung (2013) said PBL can improve student learning outcomes by promoting their abilities and skills in applying knowledge, solve problems, practice high-level thinking, and self-directing and reflecting their own learning (Ceker \& Fezile, 2016). Learning with the problem based learning model begins with problems that in this case can be raised by students and teachers, then students deepen their knowledge about what they already know or what they need to know to solve the problem. Students can choose problems that are considered interesting to solve so they are motivated to play an active role in learning activities (Hizati, A., Syahrul, R., \& Arief, E., 2018).

Based on the background mentioned, the purpose of this research is to explain the process of developing learning modules write text-based discussion of problem based learning (PBL) are valid, practical, and effective.

\section{METHODS}

This type of research used in this research is the development (research and devolopment). According Sugiyono (2010, p. 407), research devolopment is a research method that is used to produce a specific product and test the effectiveness of the product. The results of this study are in the form of learning modules to write debate text.

Module development process carried out following the 4-D models suggested by Thiagarajan and Semmel (in Trianto 2012, p. 189). Model 4-D consists of four stages of development, ie define, design, develop, and disseminate. The type of data in this research is quantitative data and qualitative data. Data obtained through questionnaires, interviews, observation sheets, and test. The data analysis technique used is descriptive data analysis and use descriptive statistics to obtain the data validity, practicalities, and the effectiveness of the module.

Experiments conducted at SMAN 7 Padang. The number of study subjects were 28 students. The school election is the subject of the trial on the grounds that the school has used curriculum 2013 revised edition in 2017.

\section{FINDING AND DISCUSSION}

The development of research to produce a product in the form of text writing skills learning module based debate problem based learning (PBL) for class X SMA / MA. This module is given the title Skilled Writing Debate Text. Design module was developed in accordance with the structure of the integrated module manufacturing with a problembased approach (PBL).

Generated through learning modules, is expected to help students debate skillfully write text in accordance with the rules of language structure and text, either in groups or independently. Thus, learning is no longer centered on the teacher, but the student-centered.

Text writing skills module debate was developed using 4-D model of development (Four-D), which consists of four stages, namely define (definition), design (design), develop (development) and disseminate (spread).

\section{Phase Definition}

The results of the study to define the stages (definition) is described as follows. First, the needs analysis or the end of the preliminary analysis. The analysis of data obtained from the results of interviews conducted with Indonesian teacher at SMA N 7 Padang. The results of the analysis of these needs can be seen as follows. 
Table 1. Requirements Analysis

\begin{tabular}{cll}
\hline No. & \multicolumn{1}{c}{ Question } & \multicolumn{1}{c}{ answer } \\
\hline 1. & $\begin{array}{l}\text { What level of students' knowledge of the text a } \\
\text { debate? }\end{array}$ & $\begin{array}{l}\text { The majority is still below the limit of } \\
\text { completeness. }\end{array}$ \\
\hline 2. & $\begin{array}{l}\text { What level of debate text writing skills of } \\
\text { students? }\end{array}$ & $\begin{array}{l}\text { The majority is still below the limit of } \\
\text { completeness. }\end{array}$ \\
\hline 3. & $\begin{array}{l}\text { What mistakes are often made when writing } \\
\text { the text of the debate? }\end{array}$ & $\begin{array}{l}\text { In penyapaian opinions in writing as oral } \\
\text { written opinion. }\end{array}$ \\
\hline 4. & $\begin{array}{l}\text { What are the barriers faced by teachers and } \\
\text { students in the learning process of writing } \\
\text { texts debate? }\end{array}$ & $\begin{array}{l}\text { Looking for other learning resources to } \\
\text { add material that is not yet complete on } \\
\text { the main textbook. }\end{array}$ \\
\hline 5. & $\begin{array}{l}\text { What teaching materials used in the text } \\
\text { learning debate? }\end{array}$ & $\begin{array}{l}\text { Kemendikbud published teaching } \\
\text { materials. }\end{array}$ \\
\hline 6. & $\begin{array}{l}\text { What other learning resources used by students } \\
\text { in the learning text of the debate? }\end{array}$ & $\begin{array}{l}\text { Students seeking other sources as sources } \\
\text { on the Internet. }\end{array}$ \\
\hline 7. & $\begin{array}{l}\text { Do teachers ever apply Problem Based } \\
\text { Learning model study on the teaching of } \\
\text { writing texts debate? }\end{array}$ & Has never been \\
\hline
\end{tabular}

Based on the analysis of the needs of these students can be concluded that learning requires teachers to write text debate other learning resources to support the primary learning source.

Second,analysis of the students. Based on the analysis of students that have been done, there are two aspects that analyzed the personality and learning resources and student environment. First, the aspect of learning resourcesthat students use only one of textbooks that have come from the government. The book is a mandatory source that must be provided during the learning process. Thus, the students' understanding of the material is limited to textbooks used during the learning process. Students are actually fond of reading sources other than textbooks. In general, students more access Internet learning resources. Second, aspects of personality and environment of students. 87.5\% Students are more inclined to like the atmosphereconvenient class time to learn Indonesian, This implies that students more easily absorb the lesson when the class atmosphere is quiet and clean. There are $50 \%$ of students who prefer to learn independently. This means that students can work on writing exercises either independently or in groups.

According to Piaget's cognitive development of high school students included in the formal operational stage which is where the age range of 11-15 years. Students who are 11 years and above berusai generally been able to think in a more logical way. That is, students are able to think abstractly, reason logically, and draw conclusions from the available information (Mulyaningsih, E., 2011). As said by Piaget THAT children who are in the age range of 11-16 years has been able to think abstractly, and can make sense of SCARA logical. Both of these have no class X SMA N 7 meadow where $93 \%$ of students do not easily give up when experiencing difficulties when learning Indonesian and $87.5 \%$ of students want to be directly involved in the learning process.

Third,curriculum analysis. Based on the analysis, the curriculum used is the 2013 curriculum was revised in 2016. For the teaching of writing, which contained core competencies in the curriculum is a core competence-4, while the Basic Competence in learning to write the text contained in the KD debate 4:11 and 4:12.

Fourth, analysis of the concept. Based on the analysis of the concept, there are three aspects that are found. (1) The main concept of the learning material to write text in accordance with the formulation of the curriculum debate. Learning resources that are used by students is a book published by Kemendikbud. (2) Details of the concept of learning materials to write text debate. Details of the concept of learning materials are in accordance with the text of the debate demands of the curriculum, developed based on text-based learning. The concept of learning to write text debate debate is the notion of text, text elements debates, text kebahasan characterize the debate, and the steps to write a text debate. (3) Presentation of learning materials in learning resources. To understanding the debate in the source text is displayed in the abstract student learning. Text elements just mentioned debate only. An explanation of the elements of the debate is only explained through examples of questions about the text. So also with the characteristics of the text linguistic debate, explanation of each of these traits is not explained theoretically, but explained through examples and tasks.

\section{Phase Design}

The design of the module structure is developed in accordance with the opinions expressed Daryanto and Aris (2014: 293), which consists of three main parts, namely the introduction, learning and evaluation. However, before that 
section, there must first cover page, preface, table of contents, a map of the position of the module. Then, at the end of each module there is a list of references.

Structural modules that are designed in this study are as follows. Introductory section contains KI and KD (formulated based Curriculum 2013), prerequisites, orientation, time, and instructions for use of the module. Prerequisites unbiased knowledge or prior knowledge students need to have to learn the modules. Then, the module contains user manuals or procedures guide the use of modules, which includes instructions for using modules for teachers and students, as well as instructions for using the time to study the module.

Furthermore, part of the learning activities that include indicators of achievement of competencies, the purpose of learning activities, description of materials, summaries, assignments, tests, and worksheets practice. Part of learning activities are divided into two: the first learning activity on knowledge and learning activities 2 to aspects of skill. The learning activities in the module integrated with problem-based learning. Students are faced with a problem that is close to the students' world and the issue is becoming a public discussion. Students learn to solve a given problem, so that students skilled argued in the debate and skillful writing text text debate. This is what distinguishes this learning module with other modules.

\section{Phase Development and Phase Dissemination}

Modules are designed to be in accordance with the criteria module development. Quality module is a module that is categorized valid, practical and effective. Therefore, it is necessary to test the validity, practicalities, and the effectiveness of the modules are designed. Here are today's modules are designed validity.

Before conducting tests on modules that are designed, first be validated by experts. This is done to get the module quality and fit for use in learning. Validation is important to get an assessment of the draft modules have been prepared. This is in accordance with the opinion Emzir (2010, p. 273) states that validation is a product design assessment process carried out by providing an assessment based on rational thinking.

Before conducting tests on modules that are designed, first be validated by experts. This is done to get the module quality and fit for use in learning. Validation is important to get an assessment of the draft modules have been prepared. The validity of the results can be seen in the following table.

Table 2. Validity Value Learning Module

\begin{tabular}{lllll}
\hline No. & Rated aspect & Acquisition of Score & Validation (\%) & Category \\
\hline 1 & Aspects of Contents & 62 & 86.1 & Very Valid \\
\hline 2 & Aspects of Presentation & 77 & 96.25 & Very Valid \\
\hline 3 & Aspects of Linguistic & 23 & 95.8 & Very Valid \\
\hline 4 & Aspects of Graphics & 27 & 80 & Valid \\
\hline Total & & 189 & 89.5 & Very Valid \\
\hline
\end{tabular}

Having tested the validity and modules that are designed very valid category, further modules tested to get the value of the practicalities and effectiveness. Experiments in question is mengijucobakan teaching materials that have been validated to some samples. Practicalities test performed after the module is used by students. Results obtained from the questionnaire practicalities practicality filled out by the teacher, the practicalities questionnaire filled out by the students, and learning activities. The practicalities value is described as follows.

First, The practicalities of teachers. The practicalities value obtained through filling a questionnaire by the teacher. Results of the practicalities of the teacher can be seen in the following table.

Table 3. Results The practicalities by Teacher

\begin{tabular}{llll}
\hline No. & Rated aspect & Practicalities value (\%) & Category \\
\hline 1 & Ease in Usage & 94.6 & very Practical \\
\hline 2 & Time Used & 91.6 & very Practical \\
\hline & Value Practicality & 93.1 & very Practical \\
\hline
\end{tabular}

Second, the practicalities of students. The practicalities value obtained through filling a questionnaire by the students. Results of the practicalities of such students can be seen in the following table.

Table 3. Value practicalities by Students

\begin{tabular}{llcc}
\hline No. & Rated aspect & Practicalities value (\%) & Value \\
\hline 1. & Ease of use & 85.44 & very Practical \\
\hline 2. & Time used & 88.02 & very Practical \\
\hline Results practicalities by Students Overall & 86.73 & very Practical \\
\hline
\end{tabular}


The effectiveness of the learning module can be seen from the attitude (affective), the value of knowledge (cognitive), and the value of the skills (psychomotor). Value effectiveness can be seen in the following table.

Table 4. Value effectiveness module

\begin{tabular}{llll}
\hline No. & \multicolumn{1}{c}{ Appraisal } & Value & Predicate \\
\hline 1. & Attitude (Affective) & 93.3 & A \\
\hline 2. & Knowledge (Cognitive) & 86.0 & A \\
\hline 3. & Skills (psychomotor) & 89.0 & A \\
\hline
\end{tabular}

Furthermore, the deployment phase (disseminate). Learning modules that have been valid, practical, and effective distributed to teachers of Indonesian language study in schools of research, library school research, and distributed to teachers of subjects Indonesian in West Sumatra who are students of the Department of Indonesian Language and Literature at the University of Padang.

\section{CONCLUSION}

Based on the discussion in this study, we can conclude the following points. Some of the problems that hinder the achievement of the objectives of learning to write text debate, namely the limitations of teaching materials used. This has an impact on learning outcomes of students who still have an average below the minimum completeness criteria (KKM). Therefore, it was designed a teaching material in the form of learning modules for writing text-based discussion of problem based learning as one of the solutions to resolve the issue. In this case, the preparation of the concept of learning to write text, argues in a module developed by applying the steps of the implementation of problem based learning.

The process of developing a module at the design stage (design). At this stage, the design of the module framework and drafting modules. Perancanaan framework comprises at least learning module on the instructions of learning, competence to be achieved, content, exercises and worksheets. These components are arranged in three parts, namely the introduction, learning activities, and evaluation. At the draft stage module, conducted by making learning modules based on the module frame.

\section{References}

Adnyana, I. P. A. P., Suarni, N. K., \& Koyan, I. W. (2014). Pengaruh penerapan model pembelajaran kontekstual berbasis diskusi debat terhadap kemampuan berpikir analitik mata pelajaran PPKn ditinjau dari sikap sosial siswa X MM SMK PGRI 2 Badung. Jurnal Penelitian dan Evaluasi pendidikan, 4.

Angin, T. B. B., \& Syahrul, R. (2015). Pengembangan modul berbasis pendekatan konstektual pada materi menulis iklan di kelas viii SMP 2 Padangsidimpuan Sumatera Utara. Bahasa, Sastra, dan Pembelajaran, 3(1).

Ceker, E dan Fezile O. (2016). Features and characteristics of problem based learning. Cypriot Journal of Educational Sciences.11(4),195-202.

Daryanto dan Dwicahyono A.. (2014). Pengembangan perangkat pembelajaran (Silabus, RPP, PHB, Bahan Ajar). Yogyakarta: Gava Media.

Emzir. (2010). Metodologi penelitian pendidikan: kualitatif dan kuatitatif. Jakarta: Raja Grafindo Persada.

Festiana, I., Sarwanto, \& Sukarmin. (2014). Pengembangan modul fisika berbasis masalah pada materi listrik dinamis untuk meningkatkan kemampuan berpikir kreatif siswa sma. Jurnal Inkuiri. 3(3). 53-64.

Hizati, A., Syahrul, R., \& Arief, E. (2018). Pengaruh model problem based learning berbantuan media gambar berseri terhadap keterampilan menulis teks eksplanasi siswa kelas viii smp negeri 12 padang. Pendidikan Bahasa dan Sastra Indonesia, 7(1), 183-190.

Husniati, A., Suciati, S., \& Maridi, M. (2016). Pengembangan modul berbasis problem based learning (pbl) disertai diagram pohon pada materi fotosintesis kelas viii smp negeri 1 sawoo. Inkuiri, 5 (2), p. 30-39.

Khayati, F., Sujadi, I., \& Saputro, D. R. S. (2016). Pengembangan modul matematika untuk pembelajaran berbasis masalah (problem based learning) pada materi pokok persamaan garis lurus kelas VIII SMP. Jurnal Elektronik Pembelajaran Matematika.4(7), 608-621.

Lubis, M. S., Syahrul, R., \& Juita, N. (2014). Pengembangan modul pembelajaran bahasa indonesia berbantuan peta pikiran pada materi menulis makalah siswa kelas xi SMA/MA. Bahasa, Sastra, dan Pembelajaran, 2(1).

Mahsun. (2014). Teks dalam pembelajaran bahasa Indonesia kurikulum 2013. Rajawali Pers: Jakarta.

Melida, H. N., Sinaga, P., \& Feranie, S. (2016). Implementasi Strategi Writing to Learn untuk Meningkatkan Kemampuan Kognitif dan Keterampilan Berpikir Kritis Siswa SMA pada Materi Hukum Newton. JPPPFJurnal Penelitian \& Pengembangan Pendidikan Fisika, 2(2), 31-38.

Mulyaningsih, E. (2011). Analisis model-model pendidikan karakter untuk usia anak-anak, remaja, dan dewasa. https://scholar.google.com/scholar (Diunduh 10 September). 
Musirah. (2016). Peningkatan prestasi belajar siswa kelas v semester ii tahun pelajaran 2014/2015 sdn 1 gador kecamatan durenan trenggalek pada bidang studi pkn materi keutuhan nkri dengan menerapkan metode belajar debat. JUPEDASMEN. 2(2).

Park, C., Kier, C., \& Jugdev, K. (2011). Debate as a teaching strategy in online education: a case study. Canadian Journal of Learning and Technology/La revue canadienne de l'apprentissage et de la technologie,37(3).

Roselina. (2014). Pengembangan modul pembelajaran menulis puisi berdasarkan pendekatan stilistik untuk Siswa SMA. Lingua, Jurnal Bahasa \& Sastra. 15 (1), pp. 44-53.

Saputro, A. N. (2017). Pengembangan buku ajar menulis cerita pendek yang berorientasi pada karakter cinta tanah air. Journal Indonesian Language Education and Literature. 2 (2). Hlm. 192-202.

Sufanti, M. (2013). Pembelajaran bahasa indonesia berbasis teks: belajar dari ohio amerika serikat. Artikel. Unduh 27 Juli 2017.

Sugiyono. (2010). Metode penelitian pendidikan pendekatan kuantititif, kualitatif, dan R\&D. Sinar Baru, Bandung.

Thiagarajan, S., et al. (1974). Instructional developmen for training teacherof exceptinal children: a sourcebook: Indiana: Indiana University.

Tik, C. C. (2014). Problems Implementing Problem-Based Learning by a Private Malaysian University.Journal of Problem Based Learning in Higher Education, 2(1), hal 11-17.

Trianto. (2012). Mendesain model pembelajaran inovatif-progresif. Jakarta: Kencana.

Yulastri, A., Hidayat, H., Ganefri, Islami, S., Edya, F. (2017). Developing an entrepreneurship module by using product-based learning approach in vocational education.International Journal of Environmental \& Science Education. 12(5), 1097-1109. 